\title{
Improving Rice Yield in Tidal Floodplain: Optimizing Seedling Age and Transplanting Date
}

\author{
Abdul Hamid", ", M. Jafar Ullah², M. A. Siddique', M. Ali Akbar ${ }^{1}$, M. Matiar Rahman , \\ M. G. Neogi ${ }^{1}$, M. Faruque H. Mollah ${ }^{1}$, M. Abdur Razzaque ${ }^{3}$, M. Ashraf Hossain ${ }^{4}$ \\ ${ }^{1}$ Agrarian Research Foundation, Dhaka, Bangladesh \\ ${ }^{2}$ Agronomy Department, Sher-e-Bangla Agricultural University, Dhaka, Bangladesh \\ ${ }^{3}$ Krishi Gobeshona Foundation, Dhaka, Bangladesh \\ ${ }^{4}$ Pulses Research Center, Bangladesh Agricultural Research Institute, Joydebpur, Gazipur, Bangladesh
}

\section{Email address:}

hamid50.arf@gmail.com (A. Hamid), jafarullahsau@gmail.com (M. J. Ullah), msiddique@gmail.com (M. A. Siddique), kbdaliakbar@yahoo.com (M. A. Akbar), matiarkrishibidseed@gmail.com (M. M. Rahman), mgneogi@gmail.com (M. G. Neogi), faruque_agr@yahoo.com (M. F. H. Mollah),nilumar@gmail.com (M. A. Razzaque), ashrafbdprc@gmail.com (M. A. Hossain) ${ }^{*}$ Corresponding author

\section{To cite this article:}

Abdul Hamid, M. Jafar Ullah, M. A. Siddique, M. Ali Akbar, M. Matiar Rahman, M. G. Neogi, M. Faruque H. Mollah, M. Abdur Razzaque, M. Ashraf Hossain. Improving Rice Yield in Tidal Floodplain: Optimizing Seedling Age and Transplanting Date. Agriculture, Forestry and Fisheries. Vol. 5, No. 3, 2016, pp. 48-56. doi: 10.11648/j.aff.20160503.14

Received: April 28, 2016; Accepted: May 19, 2016; Published: June 6, 2016

\begin{abstract}
Major constraint of growing rice in south central coastal region of Bangladesh is the tidal submergence of land and crops. Indigenous rice is generally grown in tidal floodplain harvesting poor yield. Transplanting seedlings of optimum age on appropriate date may potentially increase rice yield. We carried out on-farm trials for evaluating growth and yield performance of two indigenous rice varieties (Sadamota and Lalmota) and a high yielding variety (BRRI dhan 44) in response to variable seedling age and transplanting dates for two years. In the first year, $45 \mathrm{~d}$ and $60 \mathrm{~d}$ old seedlings of Sadamota were transplanted on a single date either in rows at $40 \mathrm{~cm}$ x 40 spacing or following farmers' traditional practice of random transplanting. The second year's trial compared the performance of one indigenous variety Lalmota and one modern variety BRRI dhan 44. Two age groups ( $45 \mathrm{~d}$ and $60 \mathrm{~d}$ ) of seedlings of Lalmota and single age group ( $45 \mathrm{~d}$ ) of BRRI dhan 44 were transplanted on two different dates (August 8 and August 24). First year's trial results indicated that irrespective of seedling age, transplanting in rows produced higher yield compared with farmers' traditional practice. In the second year's trial, late transplanting of $45 \mathrm{~d}$ old seedlings of both the varieties gave higher yield compared with early transplanting. BRRI dhan 44 produced significantly higher yield than Lalmota. Late transplanting of $60 \mathrm{~d}$ old seedlings of Lalmota produced higher yield than transplanting younger seedlings. Lower yield of earlier planted rice was associated with greater hill mortality and seedling damage, and production of relatively lesser number of tillers and panicles. For increasing yield in tidal floodplain, late planting (late August) with $60 \mathrm{~d}$ old seedlings of indigenous varieties in rows $(40 \mathrm{~cm} \mathrm{x} 40 \mathrm{~cm})$ has been suggested.
\end{abstract}

Keywords: Grain Weight, Indigenous Rice Varieties, Planting Date, Seedling Age, Seedling Characters, Spikelets, Tidal Floodplain, Tillers, Transplanting Method

\section{Introduction}

Rice (Oryza sativa L.) is one of the most important cereal crops and a major food source for more than half of the world population. Globally rice is planted to over 160 million ha producing about 478 million tons of grains annually [1]. About $90 \%$ of global rice production comes from Asian countries. In terms of area and production, Bangladesh ranks fourth among the rice producing countries after China, India and Indonesia. Bangladesh produces nearly 35 million tons of rice annually. Farmers of Bangladesh grow rice in three seasons - aus, aman and boro. Until recently, aman rice ranked first in area and production. Currently, boro rice takes the lead. High yielding varieties (HYVs) and hybrids are 
planted in boro season. Also in aman season, HYVs and hybrids dominate but indigenous varieties and landraces are still being grown. There has been a massive expansion of irrigation infrastructure in the country during the past four decades that accelerated areas and productivity of high yielding rice varieties. However, in certain unfavorable ecologies farmers could not harness the benefit of HYVs. Generally indigenous varieties of rice are grown under rainfed condition in these unfavorable ecosystems. To feed the growing population the country has to increase rice production to the extent of $50 \%$ by 2025 . Major challenge of increasing production is the shrinking of cropped land due to diversion of prime lands for urbanization, industrialization and infrastructure development. Given the land scarcity, the increased production must come from increasing yield per unit area in order to meet the growing demand. Yield of modern rice apparently seems to have attained plateau and breaking the yield ceiling is not in the offing. It is therefore imperative that unless a major breakthrough in breaking the yield ceiling occurs, productivity enhancement should be searched in the unfavorable ecosystems where modern varieties have not yet been introduced. Production increase in the unfavorable ecosystems can be done either by expanding production of high HYVs or by increasing yield of indigenous varieties through improving agronomic practices.

Two unfavorable ecosystems- tidal floodplain of southern coastal districts and uplands in the Chittagong Hill Tracts together constitute over $30 \%$ of total ricelands of Bangladesh. The tidal floodplain lies generally approximately below $24^{\circ} 30^{\prime}$ North latitude covering about 2.55 million ha which is about 76 percent of the total area of the greater five coastal districts [2] and $30 \%$ of country's total cropland. Average elevation of the region is $<1.0 \mathrm{msl}$. Located in the head of Bay of Bengal, tidal floodplain in south central coastal districts is a low-lying deltaic environment that is highly vulnerable to sea level rise $[3,4]$. Cropping intensity in the southern delta region is among the lowest [5]. Topographical position and hydrological conditions present problems in growing short statured HYVs of rice in the tidal flood plain. High tides and low tides occur alternatively two times a day. At the time of the new or full moon the sun, moon, and Earth are in alignment creating extrahigh tides called spring tides. One week later, when the sun and moon are at right angles to each other, the solar tide partially cancels out the lunar tide and produces moderate tides known as neap tides. During each lunar month, two sets of spring tides and two sets of neap tides occur [6]. Because of proximity to the sea and a number of large rivers flowing down, land remains inundated for 4-6 months during rainy season and mostly indigenous varieties are adapted. The yield potential of the indigenous varieties is generally low [7, 8]. Natural hazards and low production potentiality of indigenous rice contribute to low yield in aman season. Research prior to mid-sixties of last century was limited to adoption of traditional varieties and development of manurial practices [9]. During the past several decades, rice research in Bangladesh concentrated on high yielding modern varieties. But exploring yield potential or agronomic management for increasing yield of indigenous rice varieties received little research attention. Recent research results indicate high yield potential of indigenous rice varieties and landraces $[10,11]$. Grain yield of indigenous rice can also be increased adopting better agronomic management practices [12, 13].

Seedling age at transplanting, method and date of transplanting are important factors contributing plant growth and grain yield $[14,15]$. Transplanting over-aged seedlings reduces the number of tillers and panicles per hill [16] and the number of total spikelets per unit area [17]. The benefits of transplanting younger seedlings in flood free environment with assured irrigation have been extensively reported [18, 19]. In SRI method, for example, transplanting of 8-14 d old seedlings increases number of tillers and panicles per hill. However, research aiming at generating agronomic practices for improving yield of indigenous rice varieties and landraces grown in tidal floodplain ecosystem is rather inadequate. Tidal flood causing submergence, seedling damage and tiller mortality during wet season is a common phenomenon in tidal floodplain. High tide coupled with high rainfall leads to partial or total submergence of rice plants. In many cases, young rice seedlings are too small to escape by means of underwater leaf elongation and cannot successfully develop a canopy above the water surface. Therefore, wetland rice culture in tidal floodplain requires longer seedlings that can survive variable water depths in the crop establishment phase, particularly immediately after transplanting. Farmers in south-central coastal region of Bangladesh use 60-90 d old seedlings of traditional rice varieties [20]. As the seedling age increases, higher levels of soluble sugar and starch are accumulated that contribute to better survival under tidal flood condition [21]. Seedling age is an important factor affecting the number of filled grains per panicle, the panicle length, the 1000-grain weight, and grain yield of rice [22].

Farmers in low lying areas are often forced to delay transplanting aman rice due to repeated cycles of high tides of variable depths damaging seedlings and prohibiting timely transplanting. Seedling damage and tiller mortality can be reduced shifting the transplanting date provided that rice plant gets sufficient time to develop tillers and accumulate photosynthates during pre-heading stage. Adverse effect of delaying seedling transplanting and consequential grain yield reduction in rice has been widely reported. Sanchez and Larrea [23] reported varietal difference in the response of rice to transplanting date. Delay in transplanting significantly reduced the number of effective tillers and grain yield which was attributed to poor tiller formation [24]. Generally modern varieties are more sensitive to planting date with severe yield reduction with delayed transplanting while the traditional varieties remain either insensitive or less sensitive to the variation in transplanting dates. Transplanting earlier than optimum prolongs growth duration with extended lagvegetative phase. Lodging of long duration traditional varieties causes yield reduction. Lodging can be avoided reducing plant height by delaying transplanting date $[24,25]$.

This paper reports the influence of seedling age and transplanting date on the yield of modern and indigenous 
varieties of aman rice in tidal floodplain ecosystem of Bangladesh.

\section{Materials and Methods}

\subsection{Description of Experimental Sites}

Participatory on-farm trials were conducted in two villages of Jhalakati district for two consecutive aman seasons, 2011-12 and 2012-13. Two villages - North Uttampur (22 $33.057^{\prime} \mathrm{N}$ latitude $90^{\circ} 9.704^{\prime} \mathrm{E}$ longitude) in Rajapur upazila, and Kistakathi $\left(22^{\circ} 36.163^{\prime} \mathrm{N}\right.$ latitude and $90^{\circ} 9.899^{\prime} \mathrm{E}$ longitude) in Jhalakati sadar upazila representing tidal floodplain ecosystem were selected for conducting the trial. Details of the experimental sites have been given elsewhere [26]. Six farmers from each of two villages participated in running the trials. Each farmer had devoted a plot of at least 0.134 ha for growing experimental crop. Plots in Kistakati are in close proximity of the two rivers Biskhali and Dhanshiri on both sides and connected by canals. Plots in North Uttampur are closed to the river Jangalia on the west and also not far from the river Bishkhali on the east. The distance between the two rivers at this site is nearly $1.0 \mathrm{~km}$. All the trial plots were subject to inundation due to diurnal flooding during high tides at least a week around the lunar events- full moon and new moon.

\subsection{Experimental Treatments}

The first year's study considered the effects of seedling age and planting method on the performance of a single indigenous variety Sadamota. Rice seeds (cv. Sadamota) had been planted in the seedbed on two different dates so that seedlings of two variable age groups ( $40 \mathrm{~d}$ and $60 \mathrm{~d}$ ) could be transplanted on the same date. Farmers' traditional practice of random transplanting handful of seedlings, and transplanting of seedlings in rows, $40 \mathrm{~cm}$ apart were the treatment variables. In row planting, 7 seedlings per hill were transplanted [10]. Twelve farmers were considered as replication. Because of near homogeneity of experimental sites in tidal flooding, geographical locations and proximity to rivers, locations were not considered an experimental variable. The two-factor experiment was set up in a randomized block design.

In the second year, two diversified rice varieties - BRRI dhan 44 and Lalmota were used in the experiment. BRRI dhan 44 is a medium-tall, modern variety and Lalmota is a tall, indigenous cultivar popularly grown in the tidal floodplain over generations. Seedlings of two varieties were planted in seedbed in two different dates in order to obtain seedlings of two age groups for planting on same dates. $45 \mathrm{~d}$ and $60 \mathrm{~d}$ old seedlings of Lalmota and $45 \mathrm{~d}$ old seedlings of BRRI dhan 44 were transplanted at two different times at 16 d interval- August 8 and August 24. Modern variety BRRI dhan 44 was planted with 2 seedlings per hill at $25 \mathrm{~cm} \times 15$ $\mathrm{cm}$ spacing giving 27 hills per $\mathrm{m}^{-2}$. In contrast, seedlings of indigenous variety Lalmota were sparsely planted at $40 \mathrm{~cm} \mathrm{x}$ $40 \mathrm{~cm}, 7$ seedlings per hill giving 6.25 hills $\mathrm{m}^{-2}$.

In both the years, seedlings were transplanted during low tides when tidal water level was too low to inundate experimental plots but the crop or plots were submerged during high tides. In both the years, tidal flooding partially or fully inundated the crop; but the extent and duration of flooding varied. The trial was set up in a split-split plot design accommodating planting date in the main plot, variety in the sub-plot and seedling age in the sub-sub-plot with 12 replications. Sowing seeds and seedling transplanting dates for each age group of seedlings are presented in Table 1 .

Table 1. Dates of sowing seeds in seedbed and transplanting seedlings in experimental plots.

\begin{tabular}{l|l|l}
\hline Seedling age & transplanting date & seed sowing date \\
\hline 45 & August 8 & June 27 \\
45 & August 24 & July 9 \\
60 & August 8 & June 8 \\
60 & August 24 & June 24 \\
\hline
\end{tabular}

\subsection{Collection of Data}

BRRI dhan 44 and Lalmota matured at two different dates. BRRI dhan was harvested about one month earlier than Lalmota. An area of $5 \mathrm{~m} \times 2 \mathrm{~m}$ from the central part of each plot was demarcated for determining grain yield and yield attributes. Instead of determining seedling survival rate we recorded the number of hills survived the tidal submergence counting hills of $10 \mathrm{~m}^{2}$ yield area at harvest. Grain yield of the demarcated area was determined cutting and threshing the panicles. Yield was adjusted at $13 \%$ grain moisture content. At harvest, ten hills selected from each plot at random from beyond the area for yield determination and avoiding border effect were harvested cutting at the base and plant height, the number of tillers per hill, effective and non-effective tillers per hill, number of total tillers per hill, spikelets per panicle and filled spikelets per panicle were determined. 1000-grain weight was recorded taking sub-samples from the yield area.

\subsection{Analysis of Data}

Experiments conducted in two seasons had different sets of treatment structures and hence direct comparison of two years' results could not be made. Because of different treatment structures with variable planting materials, we analyzed data of two experiments separately. The first year's experiment involved a single variety with two factors - seedling age and planting method each having two levels of treatments. Data were subjected to analysis of variance and means compared using LSD test at $\mathrm{P}<0.05$ level of significance. In the second year of experimentation, only $45 \mathrm{~d}$ old seedlings of modern variety BRRI dhan 44 were transplanted on August 8 and August 24, 2012 and for indigenous variety Lalmota, 45 and $60 \mathrm{~d}$ old seedlings were transplanted each at two different dates. Seedlings of one indigenous variety (Lalmota) and one modern variety (BRRI dhan 44) were transplanted at two different datesAugust 8 and August 24. Two age groups ( $45 \mathrm{~d}$ and $60 \mathrm{~d}$ ) of seedlings of Lalmota were used while only $45 \mathrm{~d}$ old seedlings of BRRI dhan 44 were used assuming that transplanting older seedlings of modern variety would not produce satisfactory yield. Thus the experiment was conducted seeking no 
comparison of yield performance of modern variety BRRI dhan 44 using seedlings of two variable age groups. The experimental design, however, allowed us compare the performance of early and late planted BRRI dhan 44 and Lalmota with $45 \mathrm{~d}$ old seedlings. On the other hand, intra-varietal comparison of early and late planted Lalmota could be possible planting $45 \mathrm{~d}$ and 60 $\mathrm{d}$ old seedlings at two variable dates.

Data pertaining to plant characters, yield and yield attributes were subjected to statistical analysis and means compared employing LSD test at $\mathrm{P}<0.05$ level of significance.

\section{Results and Discussion}

\section{Experiment 1}

\subsection{Effect of Seedling Age}

Both seedling age and planting method influenced growth of rice plant and production of grain yield. The effect of interaction between seedling age and transplanting method on plant characters or grain yield was not statistically significant. Transplanting of $60 \mathrm{~d}$ old seedlings gave better stand establishment showing significantly larger number of hills per unit area (Table 2). Density of hills per unit area is an important trait that eventually produces tillers per unit area. Larger number of tillers per unit area generally results in larger number of panicles to give higher yield, although the rice plant usually produces lesser number of panicles than the plant develops tillers [22]. In the present study, compared with transplanting $60 \mathrm{~d}$ old seedlings, $40 \mathrm{~d}$ old seedlings tended to produce more number of total tillers per hill but the difference was not statistically significant. On the contrary, transplanting $60 \mathrm{~d}$ old seedlings produced more effective tillers giving more panicles per unit area than $40 \mathrm{~d}$ old seedling transplanting. Larger number of panicles per unit area in the case of $60 \mathrm{~d}$ old seedling transplanting was associated with larger number of hills per unit area. It is probable that relatively older seedlings could better tolerate repeated tidal flooding after transplanting.

Table 2. Effect of seedling age and transplanting method on plant characters of rice, cv. Lalmota. 2011-2012 season.

\begin{tabular}{|c|c|c|c|c|c|c|c|c|c|}
\hline \multicolumn{2}{|l|}{ Treatments } & \multirow[b]{2}{*}{$\begin{array}{l}\text { Number } \\
\text { of hills } \mathbf{~ m}^{-2}\end{array}$} & \multirow{2}{*}{$\begin{array}{l}\text { Plant } \\
\text { height } \\
\text { (cm) }\end{array}$} & \multirow[b]{2}{*}{$\begin{array}{l}\text { Number of } \\
\text { tillers hill }^{-1}\end{array}$} & \multirow[b]{2}{*}{$\begin{array}{l}\text { Effective } \\
{\text { tillers } \text { hill }^{-1}}^{-1}\end{array}$} & \multirow[b]{2}{*}{$\begin{array}{l}\text { Non-effective } \\
\text { tillers hill }^{-1}\end{array}$} & \multirow[b]{2}{*}{$\begin{array}{l}\text { Number of } \\
\text { tillers } \mathbf{m}^{-2}\end{array}$} & \multirow[b]{2}{*}{$\begin{array}{l}\text { Number of } \\
\text { panicles } \mathbf{m}^{-2}\end{array}$} & \multirow{2}{*}{$\begin{array}{l}\text { Panicle } \\
\text { length } \\
\text { (cm) }\end{array}$} \\
\hline Seedling age (d) & $\begin{array}{l}\text { Transplanti } \\
\text { ng method }\end{array}$ & & & & & & & & \\
\hline 40 & FP & 4.98 & 134 & 26.94 & 23.17 & 3.8 & 161 & 145 & 24.1 \\
\hline 40 & RP & 5.98 & 140 & 23.33 & 19.50 & 3.8 & 168 & 156 & 22.9 \\
\hline 60 & FP & 6.12 & 138 & 21.56 & 17.67 & 3.9 & 163 & 149 & 24.6 \\
\hline 60 & $\mathrm{RP}$ & 6.74 & 139 & 26.27 & 21.73 & 4.5 & 174 & 159 & 23.2 \\
\hline $\mathrm{LSD}_{0.05}$ for seedling age & & 0.83 & ns & 1.34 & 2.16 & ns & 3.64 & 3.8 & $\mathrm{~ns}$ \\
\hline $\mathrm{LSD}_{0.05}$ for method & & 0.78 & ns & ns & ns & ns & 5.08 & 5.4 & ns \\
\hline
\end{tabular}

$\mathrm{FP}$ - farmers' practice of transplanting at random; RP- transplanting in row at $40 \mathrm{~cm} \times 40 \mathrm{~cm}$.

Table 3 shows grain yield and yield attributes of indigenous rice variety Sadamota as influenced by seedling age and planting method. Grain yield varied significantly across treatments. Averaged over planting methods, yield varied between $3,093 \mathrm{~kg}$ per ha and 3,519 $\mathrm{kg}$ per ha between two seedling age treatments. Transplanting $60 \mathrm{~d}$ old seedlings increased grain yield by $11.4 \%$ compared to planting $40 \mathrm{~d}$ old seedlings. Difference in grain yield between seedling age treatments was small but highly significant. Higher yield in transplanting $60 \mathrm{~d}$ old seedlings was associated with larger number of spikelets per panicle, total grains per hill and higher percentage of grain filling. Our results are in contrast with Ginigaddara and Ranamukhaarac [22] who obtained higher yield of rice by transplanting younger seedlings (9-12 d old) which was attributed to larger number of tiller production and greater ripening percentage. Working with irrigated rice under favorable ecosystems, many other workers [eg., 18, 27, 28, 29] also suggested transplanting younger seedlings for minimizing transplanting shock, increasing productive tillers, number of spikelets and grain filling percentage. Contrasting results in our study might be explained from the difference in ecological conditions and varietal response to tidal flooding. Repeated tidal floods of varying depths and duration caused physical damage to the rice seedlings [30] after transplanting. Our results are in agreement with that of Gill and Shahi [31] who demonstrated yield advantage of transplanting $60 \mathrm{~d}$ old seedlings over younger seedlings.

Table 3. Seedling age and planting method effects on grain yield and attributes of yield, variety Lalmota. 2011-2012 season.

\begin{tabular}{|c|c|c|c|c|c|c|c|c|}
\hline \multicolumn{2}{|l|}{ Treatments } & \multirow{2}{*}{$\begin{array}{l}\text { Spikelets } \\
\text { per panicle }\end{array}$} & \multirow{2}{*}{$\begin{array}{l}\text { Filled spikelets } \\
\text { per hill }\end{array}$} & \multirow{2}{*}{$\begin{array}{l}\text { Unfilled spikelets } \\
\text { per hill }\end{array}$} & \multirow{2}{*}{$\begin{array}{l}\text { Total grains } \\
\text { per hill }\end{array}$} & \multirow{2}{*}{$\begin{array}{l}\text { Grain } \\
\text { filling } \%\end{array}$} & \multirow{2}{*}{$\begin{array}{l}\text { 1000-grain } \\
\text { wt. (g) }\end{array}$} & \multirow{2}{*}{$\begin{array}{l}\text { Grain yield } \\
\text { (kg per ha) }\end{array}$} \\
\hline Seedling age (d) & $\begin{array}{l}\text { Transplant } \\
\text { ing method }\end{array}$ & & & & & & & \\
\hline 40 & FP & 65.38 & 1282.3 & 207.5 & 1674.2 & 87.4 & 30.03 & 2,990 \\
\hline 40 & RP & 69.98 & 1466.7 & 137.4 & 1419.7 & 89.8 & 30.28 & 3,195 \\
\hline 60 & FP & 79.10 & 1102.3 & 122.0 & 1224.3 & 90.0 & 30.85 & 3,340 \\
\hline 60 & $\mathrm{RP}$ & 89.32 & 1810.7 & 173.9 & 1984.5 & 91.3 & 31.50 & 3,698 \\
\hline \multicolumn{9}{|l|}{$\operatorname{LSD}_{0.05}$} \\
\hline for methods & & 3.77 & 211.91 & ns & 60.50 & 0.17 & ns & 113 \\
\hline
\end{tabular}

$\mathrm{FP}$ - farmers' practice of transplanting at random; RP- transplanting in row at $40 \mathrm{~cm} \times 40 \mathrm{~cm}$. 


\subsection{Effect of Transplanting Method}

Table 2 shows the influence of seedling age and planting method on agronomic characters of rice. Differences in yield related plant characters between traditional farmers' practice and transplanting in rows were rather small. Number of hills per unit area was significantly higher $\left(6.36\right.$ per $\left.\mathrm{m}^{2}\right)$ in row planting than in farmers' practice of random transplanting $\left(5.55\right.$ per $\left.\mathrm{m}^{2}\right)$. Number of tillers, effective tillers and noneffective tillers per hill did not differ significantly between the two planting methods. But the number of tillers and number of panicles per unit area was significantly higher in row planting. Such a variation was primarily due to greater number of hills retained in row-planted crop. Greater hill density in row-transplanted crop (Table 2) resulted in larger number of tillers per unit area despite uniformity in producing tillers per hill.

Grain yield varied between 2,990 $\mathrm{kg}$ per ha and 3,698 kg per ha across seedling age and planting method treatments (Table 3). Transplanting in rows markedly increased grain yield compared with random transplanting. The overall grain yield increase in row transplanted crop was nearly $11 \%$. The number of total grains per hill was more in row planted crop than randomly planted ones which was associated with greater number of spikelets and filled spikelets per panicle produced in row transplanted crop than in randomly transplanted crop. Appreciably higher percentage of grain filling and slightly increase in 1000-grain weight also contributed to increased grain yield in row transplanted crop. Our results are in agreement with Frizzell et al. [32] who obtained significantly higher yield of rice planting seeds in rows compared with broadcast seeding.

Experiment 2

\subsection{Seedling Characteristics}

Seeds were sown in the seedbed on 27 June and 9 July, 2012 for transplanting of $45 \mathrm{~d}$ old seedlings on August 8 and 24 , respectively. Data on seedling characters of two contrasting rice varieties planted at two different dates are presented in Table 4. Variety, seedling age and planting time greatly influenced the seedling vigor.

Table 4. Seedling characteristics of two contrasting rice varieties transplanted.

\begin{tabular}{lllll}
\hline Seedling age (d) & Transplanting date (seed sowing date) & Variety & Shoot length (cm) & Shoot dry weight (g) \\
\hline 45 & August 8 (27 June) & BRRI dhan 44 & 40.21 & 1.437 \\
& August 8 (27 June) & Lalmota & 64.09 & 4.733 \\
& August 24 (9 July) & BRRI dhan 44 & 36.4 & 1.403 \\
& August 24 (9 July) & Lalmota & 63.34 & 4.45 \\
60 & August 8 ( 8 June) & Lalmota & 75.917 & 6.947 \\
& August 24 (24 June) & Lalmota & 86.487 & 8.277 \\
$\mathrm{CV}(\%)$ & & 17 & 3.019 & 0.236 \\
$\mathrm{LSD}_{0.05}$ & & & & 12 \\
\hline
\end{tabular}

Effect of sowing date: Seedlings raised from 27 June sowing were generally taller and heavier than the seedlings of 9 July sowing. Environmental conditions prevailing during 45 days in the seedbed prior to transplanting might have influenced in creating such variation. Regardless of planting time, $45 \mathrm{~d}$ old seedlings of Lalmota were significantly taller and heavier than seedlings of BRRI dhan 44. Shoot length of $45 \mathrm{~d}$ old seedlings of BRRI dhan 44 for August 8 planting was $44.21 \mathrm{~cm}$ as against $64.09 \mathrm{~cm}$ of Lalmota - a height difference of $59.4 \%$. Likewise, seedling height of BRRI dhan 44 for 24 August planting was 36.4 $\mathrm{cm}$ while the seedlings of Lalmota $(63.34 \mathrm{~cm})$ was over $74 \%$ higher than BRRI dhan 44 . Dry weight of $45 \mathrm{~d}$ old seedlings of Lalmota was also much higher than that of BRRI dhan 44. The difference in seedling dry weight was more conspicuous than seedling height. The corresponding differences in seedling dry weight of two varieties at two different times were $332 \%$ and $317 \%$, respectively. From the results, it appears that seedling vigor of indigenous variety Lalmota was much higher than that of modern variety BRRI dhan 44. Seedling of BRRI dhan 44 of same age planted on two different dates showed marked variation in shoot height and dry matter accumulation. Late seeding depressed dry matter accumulation and seedling height in BRRI dhan 44 only but not in Lalmota.

Phenological development: Rice varieties differed greatly in days taking to phenological events (Table 5). BRRI dhan 44 attained panicle initiation stage about one month earlier than the indigenous variety Lalmota. BRRI dhan 44 had taken 107 days for flowering as against 143 to 144 days by Lalmota. Time to flowering has been an important trait for improving crop productivity and adaptation [33] since the maximum yield in a growing season is largely determined during the pre-flowering period [34]. Time taken to maturity ranged between 139 days and 184 days across variety and planting date treatments. As expected, compared with modern variety BRRI dhan 44, indigenous variety Lalmota had taken 38 to 45 days more to mature. Seedling age or planting date appears to have no significant influence on the time required to attain any phenological event. 
Table 5. Seedling age and transplanting date effects on the days taken to attain phonological events of two varieties of rice.

\begin{tabular}{lllll}
\hline Treatment & Days to panicle initiation & Days to flowering & Days to physiological maturity & Days to harvest \\
\hline BRRI 44, 45 d (8 Aug) & 80.7 & 106.7 & 143.0 & 150.0 \\
BRRIdhan 44, 45 d (24 Aug) & 81.3 & 107.3 & 138.7 & 147.3 \\
Lalmota, 45 d (8 Aug) & 118.7 & 145.0 & 179.3 & 188.3 \\
Lalmota 45 d (24 Aug) & 117.0 & 143.7 & 170.3 & 178.3 \\
Lalmota 60 d (8 Aug) & 118.7 & 144.0 & 184.3 & 192.3 \\
Lalmota 60 d (24 Aug) & 117.3 & 143.3 & 179.7 & 188.3 \\
LSD $_{0.05}$ & 5.8 & 6.3 & 8.1 & 9.8 \\
\hline
\end{tabular}

Plant characters: Table 6 summarizes hill density, tillers per hill, tillers per unit area, shoot dry mass, grain yield and harvest index of two varieties of rice planted with variable seedling ages and on variable dates. There was striking difference in population density between modern- and indigenous varieties. This was partly due to the design of the experiment and partly due to variable tillering patterns of diverse rice varieties. Two different planting configurations were maintained at the time of transplanting seedlings. In view of vigorous tillering capacity of indigenous variety [35], the population density of Lalmota was kept low deliberately by transplanting seedlings at $40 \mathrm{~cm} \times 40 \mathrm{~cm}$ configuration. Recommended planting configuration of modern variety (25 $\mathrm{cm} \times 15 \mathrm{~cm}$ ) was maintained following standard practices [36]. Thus the initial population densities of BRRI dhan 44 and Lalmota were 27 and 6.25 per $\mathrm{m}^{2}$ respectively. As observed in previous year's experiment, hill densities retained at harvest time were appreciably less than originally established at transplanting. Initial hill density of BRRI dhan 44 had 4.3 times higher than that of Lalmota. But the hills established at transplanting could not be maintained due to repeated cycles of tidal submergence of the field. Deducting the hills retained at harvest from the hills originally established gives the mortality figures. Flooding depth during high tide immediately after transplanting varied between 36 $\mathrm{cm}$ and $52 \mathrm{~cm}$ (data not shown). Repeated cycles of flooding might have caused hill and tiller mortality. Hill mortality was more in modern variety BRRI dhan 44 than in Lalmota. It was nearly $37.5 \%$ in BRRI dhan 44 compared to $13.6 \%$ in Lalmota using $45 \mathrm{~d}$ old seedlings. In Lalmota, hill mortality was more when relatively younger ( $45 \mathrm{~d}$ old) seedlings were transplanted. Hill mortality was substantially reduced when $60 \mathrm{~d}$ old seedlings of Lalmota were late planted (24 August). Earlier planting (August 8) resulted in higher percentage of hill mortality presumably because of tidal submergence enduring for a longer period.

Plant height ranged between 114.6 and $167.2 \mathrm{~cm}$ across varieties and planting dates (Table 6). Variety Lalmota had the longest plants and BRRI dhan 44 produced the shortest. Seedling age at transplanting or date of transplanting had little influence on plant height.

Table 6. Seedling age and transplanting date effects on grain yield and yield components of two contrastingrice varieties grown in tidal floodplain.

\begin{tabular}{|c|c|c|c|c|c|c|c|c|}
\hline variety & $\begin{array}{l}\text { Seedling } \\
\text { age (d) }\end{array}$ & Planting date & $\begin{array}{l}\text { Hills per } \mathrm{m}^{2} \text { at } \\
\text { harvest }\end{array}$ & Plant ht (cm) & $\begin{array}{l}\text { Tillers per } \\
\text { hill (number) }\end{array}$ & $\begin{array}{l}\text { Panicles per } \\
\text { hill (number) }\end{array}$ & $\begin{array}{l}1000-g r \\
\text { wt (g) }\end{array}$ & $\begin{array}{l}\text { Grain yield (kg } \\
\text { per ha) }\end{array}$ \\
\hline \multirow{2}{*}{$\begin{array}{l}\text { BRRI } \\
\text { dhan } 44\end{array}$} & \multirow[t]{2}{*}{45} & August 8 & 12.8 & 114.6 & 11.4 & 10.0 & 25.373 & 2436 \\
\hline & & August 24 & 21.0 & 114.7 & 12.3 & 11.7 & 27.667 & 4575 \\
\hline \multirow{3}{*}{ Lalmota } & 45 & Aug 24 & 3.98 & 164.6 & 27.9 & 24.00 & 27.667 & 3518 \\
\hline & \multirow{2}{*}{60} & Aug 8 & 3.84 & 160.1 & 30.11 & 26.56 & 28.840 & 2689 \\
\hline & & Aug 24 & 4.07 & 167.2 & 34.11 & 30.56 & 30.067 & 3667 \\
\hline \multicolumn{2}{|c|}{ for seedling age } & & $\mathrm{ns}$ & ns & 2.62 & 1.93 & ns & 118 \\
\hline \multicolumn{2}{|c|}{ for planting date } & & 0.26 & 2.02 & 2.11 & 2.14 & ns & 163 \\
\hline \multicolumn{2}{|c|}{ for three-way interaction } & & $\mathrm{ns}$ & ns & 1.67 & $\mathrm{~ns}$ & ns & 837 \\
\hline
\end{tabular}

Varieties differed significantly in the number of tillers per hill (Table 6). When transplanted with $45 \mathrm{~d}$ old seedlings, the number of tillers per hill ranged from 11.9 to 26.8 between the varieties. The number of tillers and panicles per hill was nearly three times higher in Lalmota than in BRRI dhan 44. Late planting generally increased the number of tillers per hill. Likewise, the use of older seedlings markedly increased the number of tillers and panicles per hill, and grain weight. The number of tillers per hill increased by about $20 \%$ when $60 \mathrm{~d}$ old seedlings were transplanted compared with transplanting younger seedlings. Transplanting older seedlings resulted in $67 \%$ increase in panicles per hill (Table 6).

Hill density: Planting configurations of indigenous $(40 \mathrm{~cm}$ x $40 \mathrm{~cm}$ ) and modern variety $(35 \mathrm{~cm}$ x $15 \mathrm{~cm}$ ) were same for early- and late transplanting or the use of $45 \mathrm{~d}$ - and $60 \mathrm{~d}$ old seedlings. The hill densities established for indigenous and modern varieties at transplanting were 6.25 and 27 per $\mathrm{m}^{2}$, respectively. Transplanting $60 \mathrm{~d}$ old seedlings resulted in greater number of hills retained per unit area at harvest that transplanting younger seedlings. The difference between the hill densities at transplanting and at harvest indicates the loss of tillers due to mortality. Table 6 shows that regardless of variety or seedling age, early transplanted rice had significantly lower number of hills per $\mathrm{m}^{2}$. Reduction of hills in BRRI dhan 44 was $53 \%$ in early planting which was $22 \%$ in late planting. In Lalmota, loss of tiller was generally high 
in transplanting $45 \mathrm{~d}$ old seedlings. Loss of hills could be reduced to some extent by planting older seedlings. Early planting increased the loss of hills. Hill density retained till harvest was found to be positively and linearly associated with seedling shoot length and seedling dry mass at transplanting. Longer the seedling height or greater the seedling dry mass at transplanting, larger was the number of hills survived in flooding. Higher yield in late transplanted rice was associated with larger number of hills that endured tidal floods.

Grain yield: Data on grain yield and yield attributes are presented in Table 6. Variety, seedling age and date of transplanting greatly influenced grain yield and yield attributes. Gain yield ranged between 2,283 and 4,575 kg per ha $^{1}$ across variety, seedling age and transplanting date treatments (Table 6). It was highest for BRRI dhan 44 and lowest for Lalmota planted with $45 \mathrm{~d}$ old seedlings. Late transplanting of BRRI dhan 44 with $45 \mathrm{~d}$ old seedlings produced the highest yield $(4,575 \mathrm{~kg}$ per ha) compared with Lalmota transplanted on same date with seedlings of similar age $(3,518 \mathrm{~kg}$ per ha). Grain yield of Lalmota increased by nearly $10 \%$ when $60 \mathrm{~d}$ old seedlings were transplanted compared with $45 \mathrm{~d}$ old seedlings. In Lalmota, transplanting 60 day old seedlings gave higher yield of rice regardless of transplanting dates. Grain yield did not differ significantly between the two varieties in Aug 8 transplanting; but marked variation in yield was observed for Aug 24 transplanting. Late planted BRRI dhan 44 produced highest yield $(4,575 \mathrm{~kg}$ per ha) among all the treatments. Early planting (Aug 8) reduced grain yield by $47 \%$. Early planting also reduced grain yield in Lalmota but the reduction rate was less $(35 \%)$ compared with modern variety. Working in non-saline wetland situation, Roy et al. [37] also obtained highest yield transplanting seedlings of HYVs in September. Transplanting $60 \mathrm{~d}$ old seedlings could further lessen the reduction rate $(27 \%)$ in early planted Lalmota rice. Our findings are in agreement with Pandeet al. [38] who reported that grain yield of rice increased with the increase of seedling age in intermittent flooded area. Older seedlings, which have greater submergence tolerance, contain more carbohydrates. It is probable that indigenous variety Lalmota could use greater amount of carbohydrates during the recovery period [39].

Grain yield is the function of the number of panicles per unit area, number of spikelets per panicle, grain filling rate or percentage of filled spikelets and grain weight. The number of panicles per unit area depends largely on the hill density and the number of productive tillers per hill. Regardless of planting time, the number of panicles per hill was nearly three times higher in Lalmota than in BRRI dhan 44. 1000grain weight tended to be higher in Lalmota compared with BRRI dhan 44 but did not differ significantly among the treatments. Despite larger number of tillers and panicles per hill, the sparsely planted Lalmota could not compensate for the total number of tillers or panicles per unit area that eventually resulted in significantly lower yield compared to that of BRRI dhan 44 .
Grain yield and associated agronomic traits of modern variety BRRI dhan 44 and two indigenous varieties Sadamota and Lalmota were compared conducting two sets of experiments in two locations representing tidal floodplain during consecutive two growing seasons. The crop being grown under non-irrigated condition relying on uncontrolled tidal floodwater, its performance depended largely on the nature of flooding and the extent of tidal submergence of the crop and crop field. Continual or intermittent high tides and consequential land and crop submergence is the characteristic feature of the tidal floodplain. Growing rice requires transplanting seedlings that can survive tidal submergence either through escape or by tolerance mechanism. Chances are better for the taller seedlings that can at least protrude apical portion of leaves above the flood level [21, 39]. Modern and indigenous rice varieties used in the experiments were of contrasting agronomic characters. There were also appreciable seasonal differences in the prevailing conditions particularly the frequency and extent of tidal submergence of the crops. Submergence tolerance and recovery ability both are equally important for lowland transplanted aman rice. Moreover, submergence tolerance and recovery ability is affected by turbidity, water temperature, duration of submergence, solar radiation, and plant characters like seedling age, seedling quality, etc. [40, 41, 42].

Results of two years' experiments reveal that rice yield could be increased by transplanting $60 \mathrm{~d}$ old seedlings compared to $45 \mathrm{~d}$ old seedlings. Our results are in disagreement with $[18,23]$ who obtained significantly higher rice yield transplanting with younger seedlings. Generally younger the seedlings transplanted, better is the yield performance [19]. In order for reducing transplanting shock, encouraging tiller development and thereby increasing grain yield, transplanting 2 week old or younger seedlings is often recommended. But in a typical tidal floodplain where ricelands remain submerged continually or intermittently with varying depths of water, major concern is establishing the crop that can escape or survive tidal floods. In the present study we demonstrated that survival of the crop following transplanting depended largely on seedling height and seedling dry mass. Seedlings of Lalmota and Sadamota being taller could tolerate floodwater better. Accumulation of greater amount of dry mass in indigenous varieties during seedling stage might have contributed to better withstand tidal floods than modern variety.

Late transplanting (August 24) of seedlings gave higher yield than planting earlier (August 8). Yield reduction due to early planting could be related with seedling or hill damage due to tidal flooding. Depth of flooding and extent of submergence is usually high from late July until mid-August. Thus late planted seedlings stand better chance of surviving or escaping tidal flood.

Tillering in indigenous varieties was almost three times more than that of modern variety. The number of panicles per hill and 1000 grain weight of indigenous rice were more compared with modern variety; but yield remained low which can be attributed mainly to thinner population density. 
Seedlings of indigenous varieties were sparsely transplanted giving about one-fifth of population compared with modern varieties. Despite larger number of tillering and panicle formation, indigenous varieties could not produce sufficient number of panicles required for higher yield. For increasing the grain yield of indigenous rice varieties, population density requires to be increased.

\section{Conclusions}

Indigenous local varieties of rice are perceived to be of low yielding and non-responsive to agronomic practices. In our studies conducted in an unfavorable ecosystem, two indigenous rice varieties (Lalmota and Sadamota) responded favorably to variable planting arrangements, planting date and seedling age treatments giving significantly higher yields. Because of land topography and hydrological conditions, relatively older seedlings were used. But the yield difference was much more conspicuous between early ( 8 August) and late (24 August) transplanting. Late transplanting of $45 \mathrm{~d}$ old seedlings produced over $71 \%$ higher yield than early transplanting. Modern variety BRRI dhan 44 gave higher yield than indigenous variety Lalmota although the magnitude of yield differenceis not high. Transplanting $60 \mathrm{~d}$ old seedlings produced significantly higher yield compared with using $45 \mathrm{~d}$ old seedlings in variety Lalmota. In absence of high yielding varieties suitable for growing in tidal floodplain, farmers can substantially increase grain yield and profit by transplanting $60 \mathrm{~d}$ old seedlings of indigenous varieties during later part of August.

\section{Acknowledgements}

Krishi Gobeshona Foundation (KGF) provided financial assistance for conducting the study. We thank the farmers of North Uttampur and Kistakati villages for their participation in running the trials.

\section{References}

[1] USDA ERS. Rice Yearbook. United States Department of Agriculture Economic Research Service, Washington DC., 2016.www.ers.usda.gov/data-products/rice-yearbook.aspx.

[2] FOOD AND AGRICULTURE ORGANIZATION OF THE UNITED NATIONS (FAO). Report on Tidal Area Study, Fisheries Resources Survey System. FAO/UNDPBGD/79/015. Food and Agriculture Organization of the United Nations, Dhaka, 1985.

[3] AUERBACH, L. W., GOODBRED JR, S. L., MONDAL, D.R., WILSON, C. A., AHMED, K. R., ROY, K., STICKLER, M. S., SMALl, C., GILligAN, J. M., ACKERLY, B. A. Flood risk of natural and embanked landscapes on the GangesBrahmaputra tidal delta plain. Nature Climate Change 5:153$157,2015$.

[4] OLIVER-SMITH A. Sea level rise and the vulnerability of coastal peoples: responding to the local challenges of global climate change in the 21 st century. UNU-EHS Series No.
7/2009. UNU Institute for Environment and Human Security (UNU-EHS), Bonn, Germany.56 pp, 2009.

[5] BANGLADESH AGRICULTURAL RESEARCH COUNCIL (BARC). Use of Fallow Lands and Cop Production Planning for Southern Region. Bangladesh Agricultural Research Council, Dhaka, 64 pp, 2011.

[6] SUMICH, J. L. An Introduction to the Biology of Marine Life, sixth edition. Dubuque, IA: Wm. C. Brown. pp. 30-35, 1996.

[7] AHMED, M. S., BASHAR, M. K., WAZUDDIN, M., SHAMSUDDIN, A. K. M. Morpho-physico-chemical characterization of balam rice (Oryza sativa L.) landraces of Bangladesh. Int. J. Plant Breeding \& Genetics 9(3):163-176. 2015.

[8] ISLAM, N., KABIR, M. Y., ADHIKARY S. K., JAHAN, M. $\mathrm{S}$. Yield performance of six local aromatic rice cultivars. IOSR J. Agr. Vet. Sci. 6(3):58-62, 2013.

[9] ALIM, A., SEN, J. L., ULLAH, M. T., CHOWDHURY, M. A. Review of Half a Century of Rice Research in East Pakistan. Govt. of East Pakistan, EPG Press, Dhaka.119 pp, 1962.

[10] ULLAH, M. J., RAHMAN, M. M., MOLLA, M. R. I., MOLLAH, M. F. H., ALAM, M. N., HAQUE, M. M. HAMID, A. Influence of the number of seedlings per hill on the performance of traditional rice cultivar Moulata in tidal floodplain of southern delta region of Bangladesh. Intl. J. Adv. Res. 3: 143-148, 2015.

[11] SINHA, A. K., MISHRA, P. K. Are the traditional rice varieties low yielding? A case study on traditional rice varieties of lateritic region of West Bengal. Intl. J. Advanced Res. 6: 292-296. 2015.

[12] HAMID, A., ULLAH, M. J., MOLLAH, M. F. H., AKBAR, M. A. Traditional rice varieties perform better in tidal floodplain. International J. Adv Res., 3, 1316-1321. 2015.

[13] SAITO K, LINQUIST B, ATLIN GN, PHANTHABOON K, SHIRAIWA T, HORIE T. Response of traditional and improved upland rice cultivars to $\mathrm{N}$ and $\mathrm{P}$ fertilizers in northern Laos. Field Crops Res. 96: 216-223, 2006.

[14] AMIN, A. K. M. K., HAQUE, M. A. Seedling age influence on rice (Oryza sativa L.) performance. Philippine Journal of Science, 138, 219-226. 2009.

[15] HAMID. A., ULLAH,J., HOSSAIN, A., ISLAM, A., AKHTAR, S. Response of indigenous rice cultivars to applied fertilizers in tidal floodplain of south central coastal region of Bangladesh. Acad. J. Agric. Res. 4(4): 168-175. 2016.

[16] ROY, B. C., SATTER, S. A. Tillering dynamics of transplanted rice as influenced by seedling age. Trop. Agric. 69:353-356, 1992.

[17] RAHIMPOUR, L., DALIRI, M. S., MOUSAVI, A. A. Effect of seedling age on yield and yield component of rice cultivars (Oryza sativa L.). Annals of Biological Research, 4:72-76, 2013.

[18] DEB D, LÄSSIG J, KLOFT M. A critical assessment of the importance of seedling age in the system of rice intensification (SRI) in Eastern India. Expl Agric.48: 326-346. 201. 
[19] PATRA, P. S., HAQUE, S. Effect of seedling age on tillering pattern and yield of rice (Oryza sativa L.) under system of rice intensification. ARPN J. Agril. Biol. Sci. 6(11): 33-35, 2011.

[20] SHAMSUZZAMAN, K. M., HAQUE, M. M. Performance of modern varieties of transplanted aman rice and mungbean in selected locations in tidal floodplain. In: Jafarullah, M., Ed., Crop Production in the Coastal Ecosystem-Challenges and Opportunities, Agrarian Research Foundation, Dhaka, pp. 2630,2010 .

[21] PERVIN, M. S., GOMOSTA, A. R. AHMED, J. U. Effects of age on the survival and recovery of submerged rice (Oryza sativa 1.) seedlings. Bangladesh J. Bot. 39(1): 21-28, 2010.

[22] GINIGADDARA, G. A. S., RANAMUKHAARAC, S. L. Study of age of seedlings at transplanting on growth dynamics and yield of rice under alternating flooding and suspension of irrigation of water management. Recent Research in Science and Technology 3(3): 76-88, 2011, 2011.

[23] SANCHEZ, P. A. AND LARREA, N. Influence of seedling age at transplanting on rice performance. Agron. J. 64, 828833, 1972.

[24] LIU Q, WU X, MA J, CHEN B, XIN C. Effects of delaying transplanting on agronomic traits and grain yield of ice under mechanical transplantation pattern. PLoS ONE 10(4):e0123330. 2015.

[25] MUTHUKRISHNAN, P., PONNUSAMY, K., SANTHI, P., SUBRAMANIAN, N. Effect of transplanting time on the performance of rice hybrids in Cauvery delta zone. Madras Agric. J., 87:506-507, 2000.

[26] HAMID, A., ULLAH, M. J., HAQUE, M. M., MOLLAH, M. F. H., RAHMAN, M. M. Improving grain yield of indigenous rice in tidal floodplain of southern Bangladesh: Effect of seedling age and transplanting method. Agricultural Sciences, 6, 1538-1546, 2015 http://dx.doi.org/10.4236/as.2015.612147.

[27] DEY, R., BISWAS, M., MIAH, M. N. H., MANDAL, P. Agronomic performances of rice varieties at different transplanting ages. Intl. J. Plant \& Soil Sci. 6(3): 124139(2015).

[28] PASUQUIN, E., LAFARGE, T. AND TUBANA, B. Transplanting young seedlings in irrigated rice fields: Early and high tiller production enhanced grain yield. Field Crops Research, 105, 141-155. http://dx.doi.org/10.1016/j.fcr.2007.09.001, 2008.

[29] SARKER, T K,HOSSAIN, M D, SALAM, M A, RABBANI, MG. Effect of seedling age and method of transplanting on the yield of aman rice. Progress. Agric. 24: 9 - 16, 2012.

[30] CATLING, H. D., ISLAM, Z. Effect of fertilizer on traditional deepwater rice varieties in Bangladesh, pp. 157-164. Proc. 1978 Intl Deepwater Rice Workshop. International Rice Research Institute, Los Banos, Philippines, 1979.
[31] GILL, P. S., SHAHI, H. N. Effect of nitrogen levels in relation to age of seedlings and time of transplanting on the growth, yield and milling characteristics of rice. Indian J. Agric. Sci. 57:630-634, 1987.

[32] FRIZZELL, D. L., WILSON, C. E., JR., NORMAN, R. J., SLATON, N. A., RICHARDS, A. L., RUNSICK, C. E. Influence of row spacing and seeding rate on grain yield of hybrid rice. University of Arkansas Agricultural Experiment Station Research Series 550:294-297. Fayetteville, Ark., 2006.

[33] YIN, X., STRUIK, P. C., TANG, J., QI, C. LIU, T. Model analysis of flowering phenology in recombinant inbred lines of barley. J. Exp. Bot. 56: 959-965, 2005. doi: $10.1093 / \mathrm{jxb} / \mathrm{eri089}$.

[34] SLAFER, G. A. Genetic basis of yield as viewed from a crop physiologist's perspective. Annals of Applied Biology 142, 117-128, 2003.

[35] JAHN, E, MCKAY, J. K., MAULEON, R., STEPHENS, J., MCNALLY, K. L., BUSH, D. R., LEUNG, H., LEACH, E. Genetic variation in biomass traits among 20 diverse rice varieties. 155:157-168, 2011.

[36] BANGLADESH RICE RESEARCH INSTITUTE (BRRI). Cultivation of Modern Rice. Joydebpur, Gazipur, 47 p., 2011.

[37] ROY, B. C., HOSSAIN, M. A., KHAN, M. A. I. Suitable transplanting time for modern T. Aman rice varieties in tidal non-saline wetland situation in Bangladesh. Pak. J. Biol. Sci. 6:661-665, 2003

[38] PANDE, H. K., MiTTRA, B,N., GHOSH, B. C. Flood susceptibility of semi dwarf rices and investigation on their suitability for low lying areas. In: Proceedings of the 1978 International Deepwater Rice Workshop, T. R. Hargrove, G. S. Argosino (Eds), pp. 185-195. IRRI, Los Banos, 1979.

[39] CHATURVEDI, G. S., RAM, P. C., SINGH, A. K., RAM, P., INGRAM, K. T., SINGH, B. B., SINGH, R. K., SINGH, V. P. Carbohydrate status of rainfed lowland rice in relation to submergence, drought and shade tolerance. In: Singh, V. P., Singh, R. K., Singh, B. B., Zeigler, R. S., editors. Physiology of Stress Tolerance in Rice. 1996. pp. 103-122. Proceedings of the International conference on stress physiology of rice, 1994, Lucknow, UP, India Los Baños, Philippines: International Rice Research Institute.

[40] ITO, O., ELLA, E., KAWANO, N. Physiological basis of submergence tolerance in rainfed lowland rice ecosystem. Field Crops Research 64: 75-90, 1999.

[41] JACKSON, M. B., RAM, P. C. Physiological and molecular basis of susceptibility and tolerance of rice plants to complete submergence. Annals of Botany91: 227-241, 2003.

[42] SAUTER, M. Rice in deepwater. 'How to take heed against a sea of troubles'. Naturwissenschaften87: 289-303, 2000. 